\title{
The Relationship between the Principals' Use of Power and Teachers' Job Satisfaction in Pakokku Township, Myanmar
}

\author{
Than Than Aye ${ }^{1^{*}} \quad$ Khin Mar Shwe ${ }^{2}$ \\ 1.Department of Educational Theory and Management, Sagaing University of Education, Sagaing, Myanmar \\ 2.Department of Library and Information Studies, Univeristy of Yangon, Yangon, Myanmar
}

\begin{abstract}
These objectives have been pursued throughout the duration of the study 1) to study the principals' use of Power, 2) to study the teachers' job satisfaction and 3) to investigate the relationship between principals' use of Power and teachers' job satisfaction in Basic Education High Schools in Pakokku Township, Myanmar.In this study, the quantitative research method was used. The questionnaire survey was carried out in this study. After reviewing the related literature thoroughly, a set of questionnaires to collect the required data was developed based on Principals' Use of Power of (French Jr \& Raven, 1959) and Teachers' Job Satisfaction of (Sepector, 1994). The reliability coefficient (Cronbach $\alpha$ ) was 0.753 for the principals' use of Power and 0.988 for the teachers' job satisfaction. The Principals' use of Power modified by the researcher and the teachers' jpb satisfaction was validated by exploratory factor analysis and confirmatory factor analysis and showed the good model fitting and had validity for the use in the study.Three hundred and four teachers were selected as subjects from the four Basic Education High Schools in Pakokku Township by using the random sampling method. Descriptive statistics was used to analyze the collected data. The principals' use of Power and the teachers' job satisfaction that perceived by teachers were determined as the mean value and standard deviations. Moreover, independent samples T-test and the Pearson-product moment correlation coefficient were utilized.The principals' use of power (strong level, Mean $=3.78, \mathrm{SD}=0.318$ ) and the teachers' job satisfaction (high level, Mean=3.83, $\mathrm{SD}=0.777$ ) that perceived by teachers and the relationship between principals' use of Power and teachers' job satisfaction were identified in this study. There were statistically significant differences in the use of Power and teachers' job satisfaction grouped by the school location (uban and rural). There was a typical association between principals'" use of Power and teachers' job satisfaction $(p<.01)$. Quantitative findings also suggested that the higher the principals' use of Power, the better the teachers' job satisfaction. This study gave valuable new insights into that the principals can know which types of Power should be used in the appropriate situations while working with their subordinates.
\end{abstract}

Keywords- Principals' Use of Power, Teachers' Job Satisfaction

DOI: $10.7176 / \mathrm{JEP} / 12-9-06$

Publication date:March $31^{\text {st }} 2021$

\section{Significance of the Study}

When people are interested in human resource movement, it needs to consider the communication between the superior and subordinates. In making many changes in people's everyday lives, education becomes an important field for changes. Nowadays, teachers are perceived as facilitators for the acquisition of knowledge than disseminators of knowledge in education. Additionally, teachers' job satisfaction may also be related to their perceptions of other aspects of the school.

This is a very powerful property for educational leaders and teachers as professionals because it results in better understanding of the relationship between the principals' use of Power and teachers' job satisfaction for promoting organizational and professional goals. When principals understood how their use of Power is related to the teachers' job satisfaction, they can give strong support and handle their teachers in their organization for the accomplishments of the work effectively and smoothly. Since the use of these different bases of Power can be perceived more or less positively by workers, it is likely that teachers with higher job satisfaction will consider their principals to be using a different kind of Power than will teachers with lower job satisfaction.

\section{Bases of Power}

In the workplace, it becomes useful to study particular aspects of Power used by the principals with the administrative and political aspect. Power is the most widely used tool in organizations and this has been shown to be a powerful method for the organization existence. This means that Power is very important tool in achieving organizational goals and objectives. It highlights that if leaders know their Power and how to use it effectively, they can create and achieve the desired results intellectually. By learning how Power operates in organizations, one will be better able to use that knowledge to become a more effective leader (Zogjani, Llaci, \& Elmazi, 2014).

French Jr and Raven (1959) explored five bases of social Power that needed and influenced the leaders to deal with the subordinates for the good relationship between them. Based on the Power they have, their trait abilities, qualities, skills and characteristics become different as characteristics of a person and their position for their existence and stance. When an individual was provided a base of Power, he/she was provided a platform on 
which to direct subordinates to do as he/she requests. People exercise their Power in various ways as they know the position of Power that sometimes come from the position they possessed.

This provides a solid foundation on which better understanding on social Power and how people try to influence others to change something by the work of French Jr and Raven (1959). The nature of Power is derived from individual who has Power and subordinate under him. For the purpose of this study, the power bases was limited to the seven identified as (a) reward power, (b) coercive Power, (c) legitimate Power, (d) referent power, (e) expert power (French and Rave, 1959, 2011), with the addition of (f) information power, and (g) connection power studied in Hersey, Blanchard, and Natemeyer (1979).

"Within the exercise of Power there was ovelap among the sources of Power although each base varies in its number of dimensions and strategies. It can also be clearly seen that it is possible to use more than one type power by a person, resulting an overlap of bases.

Leaders give their followers rewards for their efforts and achievements of goals as identified as reward power. They understand that in running the organization, the use of reward power can be combined with another management strategy and it becomes the strength point. It can be seen that if a subordinate is trying to get some information beyond the limit pertaining to a facet of the goal, the leader can use legitimate power base strategy and and provide the subordinate a measure of dispersed information which may be viewed las a reward for their efforts.

Grahlam (2015)'s study explored that reward power and coercive Power can be used in combination with other power bases that can make the organization more effective. Leaders will give punishments in order to force someone for competing the goal in time. For instance, if the leader tended to obey the follow of the information, he or she can use coercive Power.

Legitimate Power derived formally from the leaders' position. As they are in higher management position, they have the right to apply their legitimate Power to their subordinates. Since leaders had authority given them based on the position they maintain, they also had access to controlling the flow of information and the direction of information. Leaders can utilize their position to control information, ensuring that their directives and requests are acted upon.

In some situations, the leader can use the referent power possessed as based on their personality traits. Executing referent power basically needs socialization and interactions with others. The leader get the referent power from the impressions of the audience. The leader who applied the referent power strategy is interested in talking with subordinates that can become confident in the leader's ability and follow his or her directives. The use of power-talk "allows an individual to be viewed as powerful, through the use of semantics, sentence structure, pitch, volume and clarity". Subordinates were more likely to follow individuals who presented themselves in a confident manner and brought assurance. Leaders who exerted referent power often were "precise, concise, rational, logical and calm". Through the utilization of power-talks, not only did the leader engage the subordinates in referent power strategies, but also utilized some degree of expert power base strategies. "In order for followers to attach value to a leader's words the communication must reflect the leader's know-how, experience, expertise, confidence, and competence".

When trying to understand the concept of leadership, Power include in the considerable area because Power can influence the whole process. It can be known that when people have the influence on others' ideas, beliefs and courses of action, they possess Power. While someone tries to use Power, it is their attempt to get the desired results. Power exists and affect the relationship between the two agents- a leader and a subordinate. The leader gained a platform of Power from the position they held over the subordinate and existent between the two is an influential relationship. Subordinates perceived their leader as someone who had positional Power and therefore had the ability to request, direct, command and impose accordingly. The principal's use of Power in their schools has relations to teachers' job satisfaction with the work and their principals. There is also teachers' dissatisfaction with work and their principals when principals used coercive Power, connection power and reward power. High school principals used more referent power and expert Power to influence and relied little on coercive Power or reward power. Power is the ability to influence others. One of the most influential theories of Power comes from the work of French and Raven who attempted to determine the sources of power leaders use to influence others. French and Raven identified five sources of Power which are legitimate, reward, coercive, expert and referent.

(1). Legitimate Power is that the principals can influence the behavior of subordinates because of formal position.

(2). Reward power is that the principals can influence subordinates by rewarding their desirable behavior.

(3). Coercive Power is that the principals can influence subordinates by purnishing them for undesirable.

(4). Expert Power is that the principals can influence subordinates' behavior on the basic of specialized knowledge and skill.

(5) Referent power is that the principals can influence behavior based on subordinates' liking and identification with the administrator.

(6). Information power is that on the principals can possess and distribute information. Principals withholds 
information or provides information to subordinates as needed in order to ensure compliance.

(7). Connection power is that the principals can connect with influential or important people. A principal high in connection power induces compliance than others because they try to gain favor or avoid disfavor of the powerful connection.

\section{Job Satisfaction}

An employee can describe his or her job satisfaction by evaluating his or her job as favorable or unfavorable. It is the positive response and feelings that employees have on their job. Job satisfaction is an expression used to describe the attitude an employee has towards the job and associated roles and responsibilities, where a highly satisfied employee will have a positive attitude and vice versa.

Work. Work that satisfies the needs of employees is work providing an opportunity to use one's valuable skills and abilities, creativity and variety. Also work which has just sufficient difficulty, amount of work, responsibility, autonomy and complexity.

Income. When the difference between valued pay and the obtained pay arises the income satisfaction. People with higher income are more satisfied with their job than individuals with lower income. But money cannot be termed as the most determinant factor contributing to job satisfaction but money does make things while. Income level is associated with status, lifestyle and independence.

Working Conditions. Generally, employees are satisfied with physical surroundings which are not dangerous or uncomfortable. Moderate rather than extreme degrees are preferred, since extremes cause physical comfort and reduce ability of work. Most employees also value a location close to home, new buildings, cleanliness, and adequate tools and equally as working conditions.

Self Esteem. One of the subjects in the area of job attitudes is the individual's views of himself and how various job experiences and conditions affect him. Persons who are high in self-esteem or who have a positive self-image appear to be more satisfied with their jobs.

Policy and Management. The organization has more ultimate, control over these factors than the employee's immediate supervisor. The organization policies which are incomplete, unclear or undefined have been found to be associated with job satisfaction.

Intrinsic Rewards. Professionals derive greater rewards from works, including the challenge of their work, the use of the skills and knowledge, the opportunity for self-development, learning and growth.

Interpersonal Relations. Friendly and positive relation with coworkers subordinates and supervisors contribute to high level of job satisfaction.

\section{Purpose of the Research}

The main purpose of the research is to study teachers' perceptions on their principals' use of Power and their job satisfaction in Basic Education High Schools.

The specific objectives are as follows.

1. To examine teachers' perceptions on their principals' use of Power

2. To examine the level of teachers' job satisfaction

3. To examine the relationship between the principals' use of Power and the teachers' job satisfaction

\section{Research Questions}

The following research questions are used to guide this study.

1. What kinds of Power do the principals mostly use, as perceived by teachers?

2. What is the level of teachers' job satisfaction?

3. What is the relationships between the teachers' perception of the principal's use of power and their selfperceptions job satisfaction?

\section{Limitations of the Study}

The following points show the scope of the study.

(1) The study is geographically restricted to Pakokku Township.

(2) Participants of the study are principals and teachers from four Basic Education High schools of Pakokku Township; two from urban and two from rural

(3) This study is designed to investigate the relationship between principals' use of Power and teachers' job satisfaction in Pakokku Township.

\section{Definition of Key Terms}

This part defines a number of important aspects related to the subject of this study.

Principals' Use of Power - the ability to guide others to the needed behaviors .(Altinkurt \& Yilmaz, 2012)

Teachers' Job Satisfaction-the terminology used to describe whether employees are happy and contented and 
fulfilling their desires and needs at work

\section{Methodology}

\subsection{Quantitative Study}

In this study, questionnaire survey was carried out to investigate the relationship between principals' use of Power and teachers' job satisfaction. The questionnaire consisted mainly of closed-ended questions. For the closed-ended questions, the five point Likert-type items for principals' use of Power and teachers' job satisfaction.

\subsection{Sample}

In order to obtain the representative sample, four Basic Education High Schools in Pakokku Township were selected by random sampling method. The target population for this study consisted of 304 teachers from four Basic Education High Schools in Pakokku Township, Magwe Region. The participants comprised 100 Senior Teachers, 104 Junior Teachers and 100 Primary Teachers in this study.

\subsection{Instrumentation}

The main tools of data collection for this study were questionnaires. Under the guidance of the supervisor, two sets of questionnaire were constructed by the researcher in order to obtain the necessary information. They were employed in the study for the teachers. The questionnaire for teachers was used to collect data concerning on their principals use of Power and teachers' job satisfaction.

The questionnaires were based on French and Raven's Use of Power for principals' use of Power in the schools and Spencer's Job Satisfaction for teachers' job satisfaction. The Principals' use of Power included seven dimensions: referent power (6 items), reward power (6 items), expert Power (6 items), coercive Power (5 items), legitimate Power (6 items), information power (5 items) and connection power (4 items). Teachers' Job Satisfaction questionnaire included 36 items. Teachers rated their agreement or disagreement with each items for the seven dimensions of their principals' use of Power and teachers' job satisfaction using a five-point Likert scale: strongly agree (coded as 5), agree (coded as 4), neutral ( coded as 3), disagree( coded as 2 ) and strongly disagree (coded as $1)$.

In developing the instruments, consultation was made with the experts on their review and comments and modified incorporation with the suggestions of the experts. For the reliability and validity for the instrument, the Cronbach's alpha coefficient for the Principals' Use of Power was 0.753 and Teachers' Job Satisfaction was 0.988.

-Construct Validity. The responses are based on 5-point Likert scale ranging from 1 (strongly disagree) to 5 (strongly agree). All measures are within the acceptable range of Skewness $>2$ (George \& Mallery, 2010) and Kurtosis $>7$ (Byrne, 2013), suggesting that they are normally distributed. The exploratory factor analysis is run for the principals' use of Power. The analysis is run with the principal component analysis and varimax-rotation. The selection of a factor and an item was based on the criteria: eigenvalue $>1$ and Scree plot and factor loadings $>.40$, respectively. The factor analysis for the principals' use of Power resulted in seven significant factors that provided support to the seven independent of the dimensions of Power with eigenvalues 14.794, 3.684, 3.042, 2.666, 1.900, 1.549 and 1.248 and for job satisfaction as one-factor model showing the eigenvalue of 25.438.

The confirmatory factor analysis for Principals' Use of Power is run as seven factor model with AMOS 21. The model fit values of $\mathrm{CMIN} / \mathrm{df}=1.614, \mathrm{NFI}=.910, \mathrm{RFI}=.902, \mathrm{IFI}=.964, \mathrm{TLI}=.960, \mathrm{CFI}=.964$ and $\mathrm{RMSEA}=.045$ showed the best model to measure the principals' use of Power. The teachers' job satisfaction one factor model also show a good model with the model fit values of $\mathrm{CMIN} / \mathrm{df}=2.184$, NFI=.901, RFI=.895, IFI=.944, TLI=.940, $\mathrm{CFI}=.944$ and RMSEA=.062. (Hair, Black, Babin, \& Anderson, 2019). Both two sets of questionnaires show a reliable instrument and valid for use.

Table 1 Summary of Measurement Scales

\begin{tabular}{|c|c|c|c|c|}
\hline Construct & Measure & Loadings & $\begin{array}{l}\text { Composite } \\
\text { Reliability }\end{array}$ & AVE \\
\hline Referent & My principal has a pleasing personality. & .868 & .933 & .835 \\
\hline \multirow[t]{5}{*}{ Power } & I don't want to identify myself with my principal. & .820 & & \\
\hline & $\begin{array}{l}\text { I admire my principal because he (she) treats every person } \\
\text { fairly. }\end{array}$ & .841 & & \\
\hline & I like the personal qualities of my principal. & .718 & & \\
\hline & $\begin{array}{l}\text { I want to develop a good interpersonal relationship with my } \\
\text { principal. }\end{array}$ & .870 & & \\
\hline & My principal is not the type of person I enjoy working with. & .895 & & \\
\hline \multirow[t]{2}{*}{$\begin{array}{l}\text { Reward } \\
\text { Power }\end{array}$} & $\begin{array}{l}\text { My principal can recommend me for merit recognition if my } \\
\text { performance is especially good. }\end{array}$ & .928 & .948 & .861 \\
\hline & $\begin{array}{l}\text { My principal can provide opportunities for my advancement } \\
\text { if my work is outstanding. }\end{array}$ & .886 & & \\
\hline
\end{tabular}




\begin{tabular}{|c|c|c|c|c|}
\hline & $\begin{array}{l}\text { My principal cannot get me a pay raise even if I do my job } \\
\text { well. }\end{array}$ & .947 & & \\
\hline & $\begin{array}{l}\text { If I put forth extra effort, my principal can take it into } \\
\text { consideration to determine my pay raise. }\end{array}$ & .941 & & \\
\hline & $\begin{array}{l}\text { My principal can get me a bonus for earning a good } \\
\text { performance rating. }\end{array}$ & .902 & & \\
\hline & $\begin{array}{l}\text { My principal can recommend a promotion for me if my } \\
\text { performance is consistently above average. }\end{array}$ & .564 & & \\
\hline \multirow{7}{*}{$\begin{array}{l}\text { Expert } \\
\text { Power }\end{array}$} & I approach my principal for advice on work-related problems & .884 & .969 & .915 \\
\hline & because he (she) is usually right. & & & \\
\hline & $\begin{array}{l}\text { When a tough job comes up my principal has the technical } \\
\text { "know-how" to get it done. }\end{array}$ & .906 & & \\
\hline & My principal has specialized training in his (her) field. & .847 & & \\
\hline & $\begin{array}{l}\text { My principal does not have the expert knowledge I need to } \\
\text { perform my job. }\end{array}$ & .963 & & \\
\hline & $\begin{array}{l}\text { I prefer to do what my principal suggests because he (she) } \\
\text { has high professional expertise. }\end{array}$ & .927 & & \\
\hline & $\begin{array}{l}\text { My principal has considerable professional experience to } \\
\text { draw from in helping me to do my work. }\end{array}$ & .961 & & \\
\hline \multirow[t]{5}{*}{$\begin{array}{l}\text { Coercive } \\
\text { Power }\end{array}$} & $\begin{array}{l}\text { My principal can take disciplinary action against me for } \\
\text { insubordination. }\end{array}$ & .897 & .959 & .908 \\
\hline & $\begin{array}{l}\text { My principal can fire me if my performance is consistently } \\
\text { below standards. }\end{array}$ & .959 & & \\
\hline & $\begin{array}{l}\text { My principal can suspend me if I am habitually late in } \\
\text { coming to work. }\end{array}$ & .947 & & \\
\hline & $\begin{array}{l}\text { My principal can see to it that I get no pay raise if my work } \\
\text { is unsatisfactory. }\end{array}$ & .802 & & \\
\hline & My principal can fire me if I neglect my duties. & .935 & & \\
\hline \multirow[t]{6}{*}{$\begin{array}{l}\text { Legitimate } \\
\text { Power }\end{array}$} & $\begin{array}{l}\text { It is reasonable for my principal to decide what he (she) } \\
\text { wants me to do. }\end{array}$ & .576 & .886 & .745 \\
\hline & $\begin{array}{l}\text { My principal is justified in expecting cooperation from me in } \\
\text { work-related matters. }\end{array}$ & .918 & & \\
\hline & $\begin{array}{l}\text { My principal's position entitles him (her) to expect support of } \\
\text { his (her) policies from me. }\end{array}$ & .836 & & \\
\hline & $\begin{array}{l}\text { My principal's position does not give him (her) the authority } \\
\text { to change the procedures of my work. }\end{array}$ & .881 & & \\
\hline & $\begin{array}{l}\text { I should do what my principal wants because he (she) is my } \\
\text { principal }\end{array}$ & .646 & & \\
\hline & $\begin{array}{l}\text { My principal has the right to expect me to carry out her (his) } \\
\text { instructions. }\end{array}$ & 612 & & \\
\hline \multirow[t]{5}{*}{$\begin{array}{l}\text { Information } \\
\text { Power }\end{array}$} & $\begin{array}{l}\text { I realize that my principal has connections with influential } \\
\text { and important persons. }\end{array}$ & .840 & .858 & .735 \\
\hline & $\begin{array}{l}\text { My principal possesses or has access to information that is } \\
\text { valuable to others. }\end{array}$ & .768 & & \\
\hline & $\begin{array}{l}\text { My principal is well-informed, up-to-date and also has the } \\
\text { ability to persuade others. }\end{array}$ & 697 & & \\
\hline & My principal has confidence in debating, or is persuasive. & .833 & & \\
\hline & $\begin{array}{l}\text { My principal knows information is essential to the successful } \\
\text { operation of the organization. }\end{array}$ & .535 & & \\
\hline \multirow[t]{3}{*}{$\begin{array}{l}\text { Connnection } \\
\text { Power }\end{array}$} & $\begin{array}{l}\text { My principal can either share or withold from subordinates } \\
\text { information in order to achieve intended results. }\end{array}$ & .695 & .834 & .742 \\
\hline & My principal can control or manipulate behaviour. & .885 & & \\
\hline & $\begin{array}{l}\text { My principal has consiousness-controlling Power as a broad } \\
\text { range of influences that include storytelling, narratives, } \\
\text { sense-making and other ways one can use to try and get } \\
\text { people to change their opinions or refine their understanding. } \\
\text { My principal tries to gain favor or avoid disfavor of the } \\
\text { powerful connection. }\end{array}$ & .771 & & \\
\hline
\end{tabular}




\begin{tabular}{|c|c|c|c|c|}
\hline Job & I feel I am being paid a fair amount for the work I do. & 0.861 & .988 & .835 \\
\hline \multirow[t]{35}{*}{ Satisfaction } & There is really too little chance for promotion on my job. & 0.808 & & \\
\hline & My principal is quite competent in doing his/her job. & 0.819 & & \\
\hline & I am not satisfied with the benefits/ incentives I receive. & 0.857 & & \\
\hline & $\begin{array}{l}\text { When I do a good job, I receive the recognition for it that I } \\
\text { should receive. }\end{array}$ & 0.827 & & \\
\hline & $\begin{array}{l}\text { Many of our rules and procedures make doing a good job } \\
\text { difficult. }\end{array}$ & 0.85 & & \\
\hline & I like the people I work with. & 0.819 & & \\
\hline & I sometimes feel my job is meaningless. & 0.843 & & \\
\hline & Communications seem good within this organization. & 0.809 & & \\
\hline & Raises in salaries are too few and far between. & 0.805 & & \\
\hline & $\begin{array}{l}\text { Those who do well on the job stand a fair chance of being } \\
\text { promoted. }\end{array}$ & 0.816 & & \\
\hline & My principal is unfair to me. & 0.826 & & \\
\hline & $\begin{array}{l}\text { The benefits/ incentives we receive are as good as most other } \\
\text { organizations offer. }\end{array}$ & 0.845 & & \\
\hline & I do not feel that the work I do is appreciated. & 0.84 & & \\
\hline & My efforts to do a good job are seldom blocked by red tape. & 0.796 & & \\
\hline & $\begin{array}{l}\text { I find I have to work harder at my job because of the } \\
\text { incompetence of people I work with. }\end{array}$ & 0.812 & & \\
\hline & I like doing the things I do at work. & 0.853 & & \\
\hline & The goals of this organization are not clear to me. & 0.795 & & \\
\hline & $\begin{array}{l}\text { I feel unappreciated by the organization when I think about } \\
\text { what they pay me. }\end{array}$ & 0.852 & & \\
\hline & People get ahead as fast here as they do in other places. & 0.836 & & \\
\hline & $\begin{array}{l}\text { My principal shows too little interest in the feelings of } \\
\text { subordinates. }\end{array}$ & 0.779 & & \\
\hline & The benefit/incentive package we have is equitable. & 0.859 & & \\
\hline & There are few rewards for those who work here. & 0.838 & & \\
\hline & I have too much to work here. & 0.878 & & \\
\hline & I enjoy my co-workers. & 0.838 & & \\
\hline & $\begin{array}{l}\text { I often feel that I do not know what is going on with the } \\
\text { organization. }\end{array}$ & 0.836 & & \\
\hline & I feel a sense of pride in doing my work. & 0.83 & & \\
\hline & I feel satisfied with my chances for salary increases. & 0.841 & & \\
\hline & There are benefits we do not have which we should have. & 0.858 & & \\
\hline & I like my principal. & 0.862 & & \\
\hline & I have too much paper work. & 0.873 & & \\
\hline & I don't feel my efforts are rewarded the way they should be. & 0.864 & & \\
\hline & I'm satisfied with my chances for promotion. & 0.843 & & \\
\hline & There is too much bickering and fighting at work. & 0.777 & & \\
\hline & My job is enjoyable. & 0.9 & & \\
\hline & Work assignments are not fully explained. & 0.823 & & \\
\hline
\end{tabular}

$\mathrm{AVE}=$ Average Variance Extracted

\section{Findings}

7.1 What kinds of Power do the principals mostly use, perceived by the teachers?

Table 2 Mean Values Showing Perceptions of Teachers on their Principals' Use of Power

\begin{tabular}{lll}
\hline No & Use of Power & $(\mathrm{N}=304)$ \\
\hline 1 & Referent Power & Mean(SD) \\
2 & Reward Power & $3.67(.905)$ \\
3 & Expert Power & $3.99(.922)$ \\
4 & Coercive Power & $3.96(.995)$ \\
5 & Legitimate Power & $3.94(1.046)$ \\
6 & Information Power & $3.79(.722)$ \\
7 & Connection Power & $3.38(.694)$ \\
\hline
\end{tabular}


According to the Table 2, decreasing order of mean values for perceptions of teachers on their principals' use of Power on reward power, expert Power, coercive Power, legitimate Power, connection power, referent power and information power was $3.99,3.96,3.94,3.79,3.75,3.67$, and 3.38 respectively.

In order to compare the principals' use of Power and teachers' job satisfaction between rural and urban areas, the t-test for independent samples was used. The results are shown in table 3.

Table 3 Independent Samples T-test Results for the Principals' Use of Power and teachers job Satisfaction

\begin{tabular}{|c|c|c|c|c|c|c|c|c|}
\hline Variables & $\begin{array}{l}\text { School } \\
\text { Location }\end{array}$ & $\mathbf{N}$ & $\mathbf{M}$ & SD & MD & $t$ & $d f$ & $p$ \\
\hline Referent & Urban & 173 & 3.91 & .691 & .568 & 5.690 & 302 & .000 \\
\hline Power & Rural & 131 & 3.34 & 1.046 & & & & \\
\hline \multirow[t]{2}{*}{ Reward Power } & Urban & 173 & 4.32 & .738 & .764 & 7.827 & 302 & .000 \\
\hline & Rural & 131 & 3.55 & .963 & & & & \\
\hline \multirow[t]{2}{*}{ Expert Power } & Urban & 173 & 4.26 & .783 & .681 & 6.267 & 302 & .000 \\
\hline & Rural & 131 & 3.58 & 1.109 & & & & \\
\hline Coercive & Urban & 173 & 3.67 & 1.120 & -.620 & -5.342 & 302 & .000 \\
\hline Power & Rural & 131 & 4.29 & .819 & & & & \\
\hline Legitimate & Urban & 173 & 3.57 & .774 & -.507 & -6.465 & 302 & .000 \\
\hline Power & Rural & 131 & 4.08 & .523 & & & & \\
\hline Information & Urban & 173 & 3.45 & .664 & .178 & 2.228 & 302 & .027 \\
\hline Power & Rural & 131 & 3.28 & .722 & & & & \\
\hline Connection & Urban & 173 & 3.95 & .686 & .460 & 5.112 & 302 & .000 \\
\hline Power & Rural & 131 & 3.48 & .884 & & & & \\
\hline Job & Urban & 173 & 4.08 & .463 & .561 & 6.664 & 302 & .000 \\
\hline Satisfaction & Rural & 131 & 3.52 & .971 & & & & \\
\hline
\end{tabular}

The table 3 shows descriptive statistics for the two school locations (Urban and rural) separately. And the independent samples test is also provided to compare the mean differences. It can be seen that urban schools were significantly different from rural schools on the principals' use of Power and teachers' job satisfaction. Inspection of the two group means indicates that the referent power, the reward power, the expert power, the information power, the connection power and the teachers' job satisfaction from urban schools are significantly higher than from rural schools. But the coercive Power and the legitimate Power are significantly lower in rural schools that in urban schools.

7.2 What is the level of teachers' job satisfaction?

Table 4 Mean Values Showing Teachers' Job Satisfaction

\begin{tabular}{lll}
\hline No. & Variable & Mean(SD) \\
\hline 1. & Job Satisfaction & $3.83(.777)$ \\
\hline
\end{tabular}

According to Table 4, mean value of teachers' job satisfaction shows that teachers have a high level of job satisfaction (3.83).

7.3 What is the relationships between the teachers' perception of the principal's use of power and their selfperceptions job satisfaction?

To examine the relationship between the teachers' perceptions of the principals' use of Power and their selfperceptions of job satisfaction, the Pearson-product moment coefficient was computed (See Table 5). 
Table 5 Correlations between Principals' Use of Power and Teachers' Job Satisfaction

\begin{tabular}{|c|c|c|c|c|c|c|c|c|}
\hline & $\begin{array}{l}\text { Referent } \\
\text { Power }\end{array}$ & $\begin{array}{l}\text { Reward } \\
\text { Power }\end{array}$ & $\begin{array}{l}\text { Expert } \\
\text { Power }\end{array}$ & $\begin{array}{l}\text { Coercive } \\
\text { Power }\end{array}$ & $\begin{array}{l}\text { Legitimate } \\
\text { Power }\end{array}$ & $\begin{array}{l}\text { Information } \\
\text { Power }\end{array}$ & $\begin{array}{l}\text { Connection } \\
\text { Power }\end{array}$ & $\begin{array}{l}\text { Job } \\
\text { Satisfaction }\end{array}$ \\
\hline $\begin{array}{l}\text { Referent } \\
\text { Power }\end{array}$ & 1 & & & & & & & \\
\hline $\begin{array}{l}\text { Reward } \\
\text { Power }\end{array}$ & $.302 * *$ & 1 & & & & & & \\
\hline $\begin{array}{l}\text { Expert } \\
\text { Power }\end{array}$ & $.328 * *$ & $.626^{* *}$ & 1 & & & & & \\
\hline $\begin{array}{l}\text { Coercive } \\
\text { Power }\end{array}$ & $-.368^{* *}$ & $-.498 * *$ & $-.455^{* *}$ & 1 & & & & \\
\hline $\begin{array}{l}\text { Legitimate } \\
\text { Power }\end{array}$ & $-.452 * *$ & $-.572 * *$ & $-.551 * *$ & $.456^{* *}$ & 1 & & & \\
\hline $\begin{array}{l}\text { Information } \\
\text { Power }\end{array}$ & $.129 *$ & $.172 *$ & $.287^{* *}$ & $-.250 * *$ & $-.343 * *$ & 1 & & \\
\hline $\begin{array}{l}\text { Connection } \\
\text { Power }\end{array}$ & $.317 * *$ & $.595^{* *}$ & $.620^{* *}$ & $-.378 * *$ & $-.539 * *$ & $.189^{* *}$ & 1 & \\
\hline $\begin{array}{l}\text { Job } \\
\text { Satisfaction }\end{array}$ & $.500 * *$ & $.718 * *$ & $.817^{* *}$ & $-.377 * *$ & $-.579 * *$ & $.418^{* *}$ & $.692 * *$ & 1 \\
\hline
\end{tabular}

**Correlation is significant at the 0.01 level (2-tailed).

Table 5 shows that the correlation between principals' use of Power and teachers' job satisfaction perceived by the teachers was statistically significant because the 'sig' is less than 0.01 . There is an association between principals use of Power and teachers' job satisfaction.

\section{Summary of the Study}

The purpose of this study was to explore principals' use of Power and teachers' job satisfaction. This study has discovered interesting relationship between principals' use of Power and teachers' job satisfaction. First, different bases of Power yielded by the principals relate to teachers' job satisfaction differently. Principals' use of reward power, referent power, expert Power, information power and connection power were found to be positively related to teachers' job satisfaction but coercive Power and legitimate Power were negatively related with theteachers' job satisfaction. Teachers' fear of punitive actions from their principals may prompt them to improve on performance but this may result in resentment towards their principals. Principals who apply connection power are more prone to increase teachers' job satisfaction while coercive Power is apt to work another way. Expert Power, referent power and information power are also becoming important as leadership is concerning collaboration and influence rather than command and control. Hopefully, these findings will provide some useful information for principals in schools as to the implications and consequences of the Power that they use when dealing with their teachers.

\section{Discussion}

Principals who are conscious about the bases of Power that they apply can help to make a significant behavioral change in their teachers towards them. A principal who is able to exemplify his or her skills to utilize the necessary power bases at the right time will be able to have teachers with higher compliance and job satisfaction.

Leaders can possess more than one type of power sources and he or she can use all these types of Power to enhance a high job satisfaction climate. It can be classified that some sources power (e.g., expert Power, referent power, connection power and reward power) come from their personality traits and abilities while other sources of Power (e.g., legitimate power. Coercive power and information power) come from their positions they are in. Yukl (1981) found that the leaders who are the most effective tend to apply person power thatn position power, but the application of this assertion to job satisfaction in the 21 st-century workplace has not been tested.

\section{Recommendation}

Each of French and Raven's (1959) each source of Power can have benefit or barriers for leaders. It is suggested that which sources of Power, or combination of sources of Power can become the most effective for the leader to create and maintain a job satisfaction climate. The further researcher should also be investigated how the personality of the leader, characteristics of employees, and the underlying culture relate and affect the different power sources. While facing challenges in maintaining a job satisfaction climate, leadership commitment is important to accomplish the tasks. It is the ability of the leaders to address the societal problems with the effective use of Power

Further research is much needed to search for a fuller understanding on how the perceived power bases of a principal influence teachers' response. From the data analysis, we could see some correlations between these bases of Power. A principal does not apply a single base of Power alone. There is a main power base that the principal 
uses and it is accompanied by secondary power bases. A principal may also use different bases of Power on different occasions or on different teachers. Further research to understand the relationship between the bases of Power will help us to further understand better. In this study, gender, age and service were regarded as they are part of the scope of the study. The differing personality traits of the teachers could result in the principals using a different base of Power for each variable or even multiple combinations of the different variables. Further studies could also look at incorporating these additional variables.

\section{References}

Altinkurt, Y., \& Yilmaz, K. (2012). Relationship between School Administrators' Organizational Power Sources and Teachers' Organizational Citizenship Behaviors. Kuram Ve Uygulamada Egitim Bilimleri, 12, 1843-1852.

Byrne, B. M. (2013). Structural Equation Modeling With AMOS: Basic Concepts, Applications, and Programming, Second Edition: Taylor \& Francis.

French Jr, J. R. P., \& Raven, B. (1959). The bases of social power. In Studies in social power. (pp. 150-167). Oxford, England: Univer. Michigan.

George, D., \& Mallery, P. (2010). SPSS for Windows step by step : a simple guide and reference 17.0 update. Boston: Allyn \& Bacon.

Graham, T. W. (2015). The relationship between the high school principal's use of power and the teachers' selfperception of professionalism.

Hair, J. F., Black, W. C., Babin, B. J., \& Anderson, R. E. (2019). Multivariate data analysis.

Hersey, P. W., Blanchard, K., \& Natemeyer, W. E. (1979). Situational Leadership, Perception, and the Impact of Power. Group \& Organization Management, 4, 418 - 428.

Sepector, P., E. (1994). Job Satisfaction Survey.

Zogjani, A. D. A., Llaci, S., \& Elmazi, M. E. (2014). THE ROLE OF POWER IN EFFECTIVE LEADERSHIP AND FOLLOWERSHIP: THE ALBANIAN CASE. Romanian Economic and Business Review, 9, 89-102.

The first author, Khin Mar Shwe currently works at University of Yangon as an Assistant Lecturer. She is studying library science $(\mathrm{PhD})$ at Wuhan University. She received her Master Degree in Library and Information Studies from Yadanabon University, Myanmar. Her current. research interests include user behavior in library and informatiom science.

The second author, Than Than Aye is an Assistant Lecturer at the Department of Educational Theory and Management, Sagaing University of Education, Myanmar serving from 2015. She was born in Yae Pyar Village, Pauk Township, Magwe Region, Myanmar in 1990. She graduated Bachelor of Education from Sagaing University of Education in 2011 and Master of Education in 2014. Her specialized filed is Educational Management, and Education Policy Reform Studies. Now she is studying the final year of PhD specializing Educational Economy and Management at Central China Normal University, Wuhan, China. 